NR 20 (29)

BIBLIOTEKA

2016 PL ISSN 1506-3615

$\begin{array}{llllllll}A & R & T & Y & K & \text { U } & \text { E } & \text { Y }\end{array}$

ALICJA SZULC

Uniwersytet im. Adama Mickiewicza w Poznaniu,

Biblioteka Uniwersytecka

\title{
Ukryte w okładce. $O$ odnalezionym dokumencie Innocentego VII z 1404 roku i opactwie cysterskim w Pomuku
}

\begin{abstract}
Streszczenie. W zbiorach rękopisów średniowiecznych Biblioteki Uniwersyteckiej w Poznaniu zidentyfikowano w 2008 roku pergaminowy dokument papieża Innocentego VII z 1404 roku, adresowany do arcybiskupa Pragi i odnoszący się do przywilejów kościelnych opactwa cystersów w Pomuku (Nepomuku) w Czechach. To obecnie najstarszy dokument (sensu stricto) w zbiorach Biblioteki. Stan jego zachowania wskazuje, że został wykorzystany wtórnie przez nieznaną introligatornię jako obleczenie drewnianej okładki kodeksu, być może również cysterskiego. List Innocentego VII typu littera exsecutoria (tj. zawierający papieskie polecenie - mandatum) ma szczególną wartość źródłową jako jeden z nielicznych ocalałych dokumentów $\mathrm{z}$ archiwum klasztoru w Pomuku, zniszczonego i rozproszonego w okresie wojen husyckich w Czechach. Artykuł zawiera edycję łacińską omawianego dokumentu.
\end{abstract}

SŁowA KLUCzowe: dokumenty papieskie, cystersi w średniowieczu, Innocenty VII, Pomuk, Nepomuk, Czechy XV wieku.

Na wyklejki i karty ochronne winien badacz rękopisu zwracać pilna uwagę i w razie potrzeby starać się o ich wyprucie, względnie odklejenie, gdyż na zszywki używano nieraz kart ze starych rękopisów, wówczas już bezużytecznych, które dziś jednak dla historyka moga być ważne. [...] Często $u \dot{y}$ wano do tego celu starych, niepotrzebnych dokumentów, niejeden też cenny dokument zachowat się do naszych czasów tylko dzięki użyciu na wyklejkę i karte ochronna.

(Władysław Semkowicz, Paleografia łacińska, 1951)

Słowa Władysława Semkowicza, wybitnego paleografa i kodykologa, przez ponad 60 lat nie straciły swojej aktualności. Wciąż są inspiracją i wskazówką dla kolejnych pokoleń badaczy średniowiecznych rękopisów. 
W 2008 roku wśród pergaminowych fragmentów rękopisów średniowiecznych Biblioteki Uniwersyteckiej w Poznaniu udało się zidentyfikować dokument papieża Innocentego VII z 1404 roku$^{1}$, adresowany do arcybiskupa Pragi i dotyczący spraw kościelnych cystersów w Pomuku $(\text { Nepomuku })^{2}$ - jednego z największych opactw cysterskich w średniowiecznych Czechach ${ }^{3}$. Poddany pełnej konserwacji dokument jest obecnie najstarszy (sensu stricto) w zbiorach Biblioteki (il. 1, 2) ${ }^{4}$.

Wartość źródłowa każdego odnalezionego dokumentu średniowiecznego jest bezsprzeczna i nie podlega dyskusji. Jednak w przypadku niektórych można mówić o znaczeniu szczególnym, zwłaszcza kiedy dokumentują one dzieje instytucji, których średniowieczne archiwalia zaginęły bądź zachowały się w stanie szczątkowym. Takim rękopisem jest list (typu littera exsecutoria) Innocentego VII z 1404 roku odnoszący się do przywilejów kościelnych opactwa w Pomuku, zniszczonego w okresie wojen husyckich. Jego ostateczną zagładę przypieczętowały w XVI wieku utrata i rozproszenie archiwum. Jak podkreśla Kateřina Charvátová, badająca dzieje cystersów w średniowiecznych Czechach: „Można tylko żałować straty 15 bull papieskich, 17 listów czeskich, 196 łacińskich i 3 kodeksów, których informacji tak bardzo byśmy potrzebowali [przeł. A.S.]" tują regesta kancelarii papieskiej, co dodatkowo zwiększa jego wartość źródłową ${ }^{6}$.

${ }^{1}$ Data wystawienia dokumentu została ustalona na podstawie pośrednich przesłanek, które omówię w dalszej części artykułu.

${ }^{2} \mathrm{~W}$ dokumentach średniowiecznych występują równolegle obie nazwy, jednak zakonnicy od początku, tj. od XII wieku, określali miejsce swojego opactwa jako Pomuk. Dopiero od XV wieku zaczęła się utrwalać i przeważać obowiązująca do dziś nazwa Nepomuk. Szerzej na temat podwójnego nazewnictwa klasztoru i miasta: K. Charvátová, D. Libal, M. Pojsl, Řád cisterciáků v českých zemich ve středověku, Praha 1994, s. 49.

${ }^{3}$ P. Vlček, P. Sommer, D. Foltýn, Encyklopedie českých klásterů, Praha 1998, s. 298. Szerzej o dziejach czeskich klasztorów cystersów w średniowieczu: K. Charvátová, D. Libal, M. Pojsl, op.cit.; K. Charvátová, Dějiny cisterckého řádu w Čechách 1142-1420. 1. svazek: Fundace 12. stoleti, Praha 1998.

${ }^{4}$ BU Rkp.7849. Konserwacja obiektu została przeprowadzona w Pracowni Restauracji Książki Biblioteki Uniwersyteckiej w Poznaniu przez konserwator mgr Renatę Kosiniec. Podstawowe informacje o prezentowanym dokumencie: A. Szulc, Bohemica w zbiorach rękopisów Biblioteki Uniwersyteckiej w Poznaniu, w: Na styku kultury polskiej i czeskiej: dziedzictwo, kontynuacje, inspiracje, red. M. Balowski, Poznań 2011, s. 290-292.

${ }^{5}$ K. Charvátová, Dějiny cisterckého řádu..., s. 214.

${ }^{6}$ Por. Acta summorum pontificum res gestas Bohemicas aevi praehussitici et hussitici illustrantia, cz. 1, wyd. J. Eršil, Praha 1980, s. 3-148. 


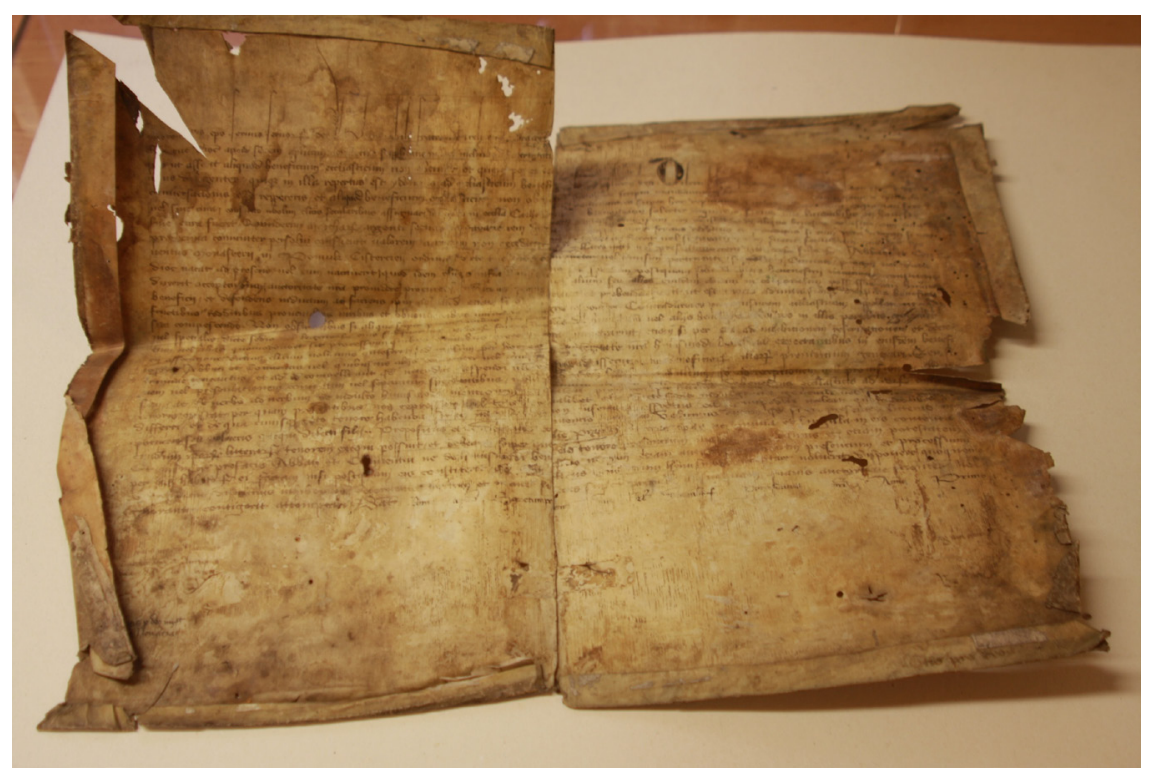

Il. 1. Dokument Innocentego VII z 1404 roku. Stan przed konserwacją Źródło: Biblioteka Uniwersytecka w Poznaniu, Rkp.7849. Fot. Renata Kosiniec.

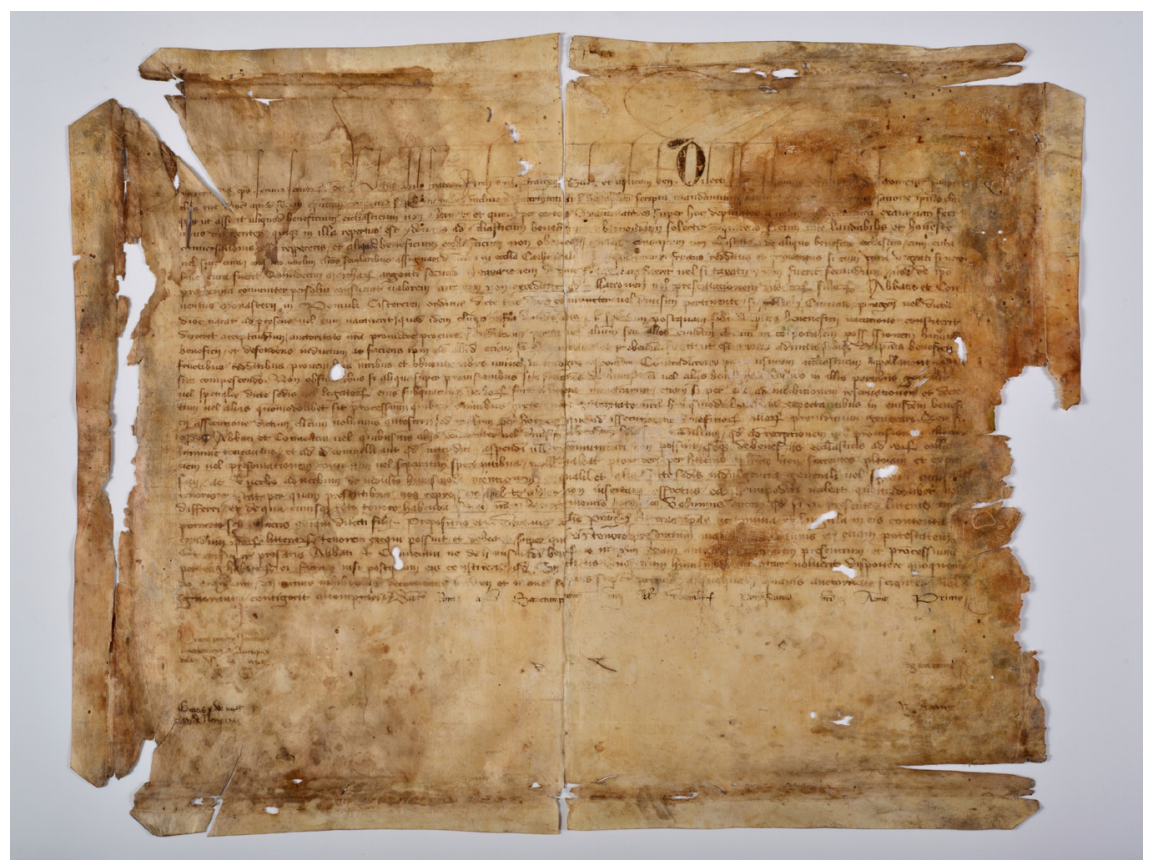

Il. 2. Dokument Innocentego VII z 1404 roku. Stan po konserwacji Źródło: Biblioteka Uniwersytecka w Poznaniu, Rkp.7849. Fot. Renata Kosiniec. 
Klasztor w Pomuku został założony prawdopodobnie w latach 1144-1145 jako czwarta filiacja frankońskiego opactwa w Ebrach i zarazem trzeci klasztor cysterski na ziemiach czeskich (Sedlec założony w 1142 roku, Plasy przed 1144 rokiem) ${ }^{7}$. Nie zachował się dokument fundacyjny opactwa i nie jest znane imię fundatora. Przypuszcza się, że mógł być nim jeden z możnowładców zachodnioczeskich bądź członek książęcego rodu Przemyślidów (być może młodszy brat Władysława II Henryk). Z pewnością jednak nie była to fundacja królewska ${ }^{8}$. Pierwszy ślad dokumentujący istnienie klasztoru pod Zeleną Horą (Zieloną Górą), nad Úslava, pochodzi z 1177 roku, kiedy to pojawia się w źródłach imię opata Konrada. Kolejną ważną datą w dziejach rozwijającego się prężnie opactwa był rok 1251. Wówczas za rządów opata Bertolda rozpoczął się proces fundacyjny klasztoru w Žd’ár nad Sázavą - pierwszej i jedynej filiacji Pomuka9.

Nie analizując drobiazgowo średniowiecznych dziejów klasztoru w Pomuku, należy wspomnieć o szczególnej kondycji ekonomicznej jednego z największych i najbogatszych opactw cysterskich na ziemiach czeskich w dobie przedhusyckiej. Na początku XV wieku opactwo posiadało 80 wsi, trzy miasteczka oraz 10 folwarków (tzw. grangii), a jednocześnie było zadłużone na wysoką sumę 12000 guldenów (florenorum auri sum$m a)^{10}$. Brak wystarczającej podstawy źródłowej, przede wszystkim zaginionych dokumentów klasztornych, pozostawia historyków jedynie

${ }^{7}$ H. Chłopocka, W. Schich, Die Ausbreitung des Zisterzienserordens östlich von Elbe und Saale, w: Die Zisterzienser. Ordensleben zwischen Ideal und Wirklichkeit, red. K. Elm, P. Joerißen, H.J. Roth, Bonn 1980, s. 93; K. Wollenberg, Die Zisterzienser in Albayern, Franken und Schwaben - ein Überblick, w: In Tal und Einsamkeit. 725 Jahre Kloster Fürstenfeld. Die Zisterzienser im alten Bayern, t. 3, red. K. Wollenberg, Fürstenfeldbruck 1990, s. 20; K. Charvátová, Der Bau der Zisterzienserklöster in Böhmen, w: Cystersi w kulturze średniowiecznej Europy, red. J. Strzelczyk, Poznań 1992, s. 181 i n.; I. Eberl, Cystersi. Historia zakonu europejskiego, Kraków 2011, s. 66.

8 Zob. K. Charvátová, Propter laudabilia abbatum merita. The Kings of Bohemia and the Cistercian Order, w: In Tal und Einsamkeit..., s. 168; eadem, Dëjiny cisterckého řádu..., s. 209.

${ }^{9}$ F. Machilek, Stiftergedächtnis und Klosterbau in der Chronik des Heinrich von Saar, w: In Tal und Einsamkeit..., s. 185.

${ }^{10} \mathrm{~J}$. Čechura, Wirtschaftsmodell der Zisterzienserklöster in Böhmen, w: Historia i kultura cystersów w dawnej Polsce i ich europejskie związki, red. J. Strzelczyk, Poznań 1987, s. 106. O specyfice gospodarki cysterskiej w średniowiecznych Czechach także: K. Charvátová, Early Cistercian economy in Bohemia (about 1150-1300): the mysterious affair of the granges, "Quaestiones medii aevi novae" 2004, t. 9, s. 283-296; eadem, Manorial farms of Cistercian abbeys of mediaeval Bohemia, w: Historia i kultura cystersów..., s. 111-135. 
w sferze domysłów: w jaki sposób kolejne pokolenia zakonników spod Zelenej Hory zbudowały tak rozległe „państwo pomuckie”, jak wyglądał proces cysterskiej kolonizacji na tej ziemi i jak doszło do tak wysokiego zadłużenia posiadłości. Na te i wiele innych pytań dotyczących historii opactwa w Pomuku próbuje się odpowiedzieć głównie na podstawie metody porównawczej, poszukując analogii w znacznie lepiej udokumentowanych dziejach innych czeskich (i nie tylko) klasztorów cysterskich doby przedhusyckiej ${ }^{11}$.

W kontekście omawianego dokumentu Innocentego VII najważniejszym dla nas zagadnieniem dotyczącym dziejów zielonogórskiego konwentu w okresie późnego średniowiecza są relacje klasztoru z kurią papieską i związana z nimi kwestia naruszania prawa patronatu, jaki posiadał opat $\mathrm{w}$ odniesieniu do beneficjów i kościołów znajdujących się $\mathrm{w}$ granicach "państwa pomuckiego". Zakon cysterski od początku swojego istnienia był w szczególny sposób związany z papiestwem i jego zadaniami ${ }^{12}$. Z grona "białych mnichów" wywodziło się wielu papieży, papieskich doradców i członków kurii. Także Pomuk miał swój udział w papieskiej służbie. Jeden z miejscowych zakonników niejaki Konrad - został powołany przez papieża rzymskiego Bonifacego IX do godności członka jego kaplicy ${ }^{13}$. Jednak już od lat 20. XIV wieku, wraz z rosnącym fiskalizmem kurii, zauważa się przejawy wyraźnej ingerencji papiestwa w wewnętrzne sprawy Kościoła czeskiego (i nie tylko) i kompetencje zastrzeżone dla lokalnej władzy diecezjalnej bądź zakonnej. Mając na względzie dobro swojej komory, papież zaczął rezerwować i rozdawać niektóre urzędy lokalne (i związane z nimi beneficja), zastrzegając je kandydatom, którzy uiścili stosowną opłatę. Również po przyjęciu obiecanego i zastrzeżonego urzędu mianowany duchowny zobowiązany był do przekazania kurii połowy dochodu z pierwszego roku swojego urzędowania. Tego rodzaju praktyki Łzw. papieskie rezerwacje - wyraźnie ograniczały prawa patronów kościołów, którzy wcześniej swobodnie rozporządzali beneficjami, wska-

${ }^{11}$ K. Charvátová, Dějiny cisterckého řádu..., s. 227-236; W. Ribbe, Die Wirtschaftstätigkeit der Zisterzienser im Mittelalter: Agrarwirtschaft, w: Die Zisterzienser..., s. 203-215; K. Elm, P. Feige, Der Verfall des zisterziensischen Ordenslebens im späten Mittelalter, w: Die Zisterzienser..., s. 237 i n.; W. Rösener, Grangienwirtschaft und Grundbesitzorganisation südwestdeutscher Zisterzienserklöster vom 12. Bis 14. Jahrhundert, w: Die Zisterzienser..., s. 137-164.

12 R. Schimmelpfenning, Zisterzienser, Papsttum und Episkopat im Mittelalter, w: Die Zisterzienser..., s. 69-85.

${ }^{13}$ Monumenta Vaticana res gestas Bohemicas illustrantia, t. 5, red. L. Klicman et al., Praha 1954, s. 482-483; podaję za K. Charvátova, Dëjiny cisterckého řádu..., s. 216. 
zując (prezentując) biskupowi własnych kandydatów na wakujące urzędy ${ }^{14}$.

W „państwie pomuckim” w ciągu XIV-XV wieku kuria kilkakrotnie ingerowała w przywileje przysługujące w tym względzie opatowi i konwentowi. Przynajmniej takie informacje można odczytać z zachowanych dokumentów papieskich. W trzech przypadkach kuria przekazała bliżej nieokreślone beneficja (w 1346, 1359 i 1406 roku), w innych konkretne probostwa - we wsi Zdemyslice (1403), Zborovy (1407 i 1412) i Nepomuk (1412), a więc trzy spośród 10 kościołów parafialnych pozostających pod patronatem miejscowych zakonników ${ }^{15}$. Jednak biorąc pod uwagę dużą liczbę prezent (a co za tym idzie - także beneficjów), jakich w tym okresie udzielały władze klasztoru, papieskie rezerwacje odgrywały w tej sferze życia Kościoła zielonogórskiego mniejszą rolę.

Odnaleziony w Bibliotece Uniwersyteckiej w Poznaniu dokument Innocentego VII powiększa zatem szczątkowy zbiór znanych dokumentów dotyczących Pomuka o kolejną papieską rezerwację beneficjum znajdującego się pod formalnym patronatem opactwa. Littera exsecutoria z 1404 roku polecająca arcybiskupowi Pragi, Zbynkowi Zajícowi z Hasenburka, powołać papieskiego kandydata duchownego na bliżej nieokreślone beneficjum kościelne jest obecnie ósmym (licząc wspomniane wyżej papieskie rezerwacje probostw) tego typu znanym dokumentem potwierdzającym ingerencję kurii rzymskiej w sprawy wewnętrzne archidiecezji praskiej i „państwa pomuckiego”.

Dokument został sporządzony na karcie pergaminowej o wymiarach $25,5 \mathrm{~cm} \times 40 \mathrm{~cm}$, czarnym atramentem, przy użyciu gotyckiej minuskuły kurialnej - pisma stosowanego $\mathrm{w}$ kancelarii papieskiej $\mathrm{w}$ późnym średniowieczu ${ }^{16}$. Stan zachowania zabytku wyraźnie wskazuje, że został on wykorzystany wtórnie - przez nieznaną introligatornię i w bliżej nieokreślonym czasie - jako obleczenie drewnianej okładki powstającego kodeksu, być może również cysterskiego. Zachował się bowiem w dwóch równo przyciętych częściach, $\mathrm{z}$ atramentowym, nieczytelnym śladem tytułu (prawdopodobnie kodeksu) na zewnętrznej stronie karty (il. 3), z wyraźnymi ubytkami, pęknięciami, śladami kleju, zagięć oraz żłobieniami

${ }^{14}$ Zob. Mateusz z Krakowa, O praktykach Kurii Rzymskiej, wyd., przeł. W. Seńko, Kęty 2007, s. 73 i n.

${ }^{15}$ Acta summorum pontificum res gestas Bohemicas, nr 260, s. 169, nr 734, s. 435; K. Charvátova Dějiny cisterckého řádu..., s. 216, 230-231, 243 (przyp. 33).

${ }^{16}$ Minuskuła kurialna (papieska), obwarowana ścisłymi zasadami już w połowie XIII wieku, przez regularność i kaligraficzność kształtu liter uznawana jest przez paleografów za jeden z najpiękniejszych duktów, „jakie zna historia pisma”; W. Semkowicz, Paleografia łacińska, Kraków 2007, s. 330. 


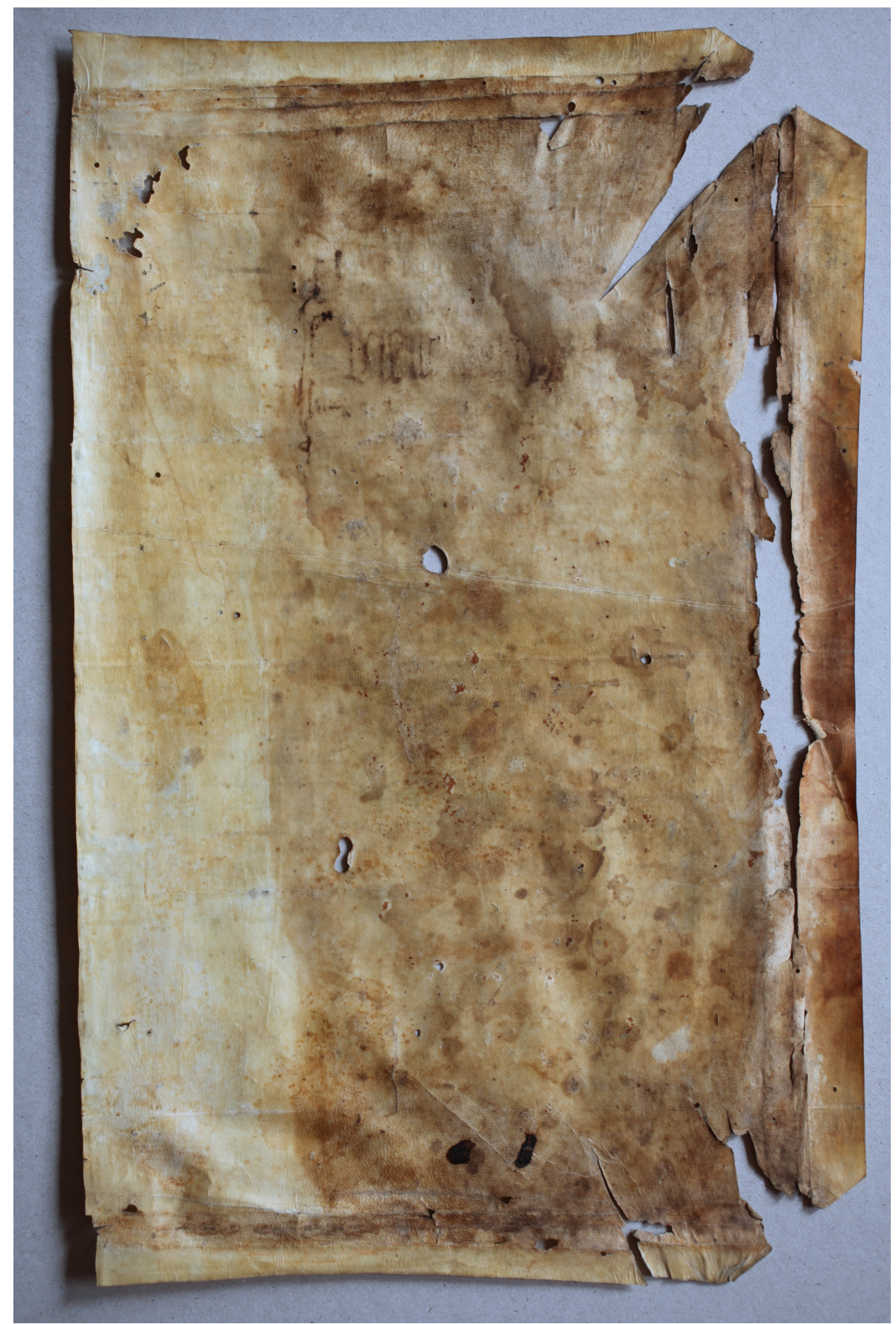

Il. 3. Dokument Innocentego VII z 1404 roku. Strona verso lewej części dokumentu Źródło: Biblioteka Uniwersytecka w Poznaniu, Rkp.7849. Fot. Renata Kosiniec. 
odzwierciedlającymi fakturę deski. Cztery podłużne nacięcia, wykonane symetrycznie u dołu obu części pergaminu (w środkowej części karty), poświadczają przywieszoną pierwotnie pieczęć - jeden z głównych środków uwierzytelniających średniowieczny dokument.

Ze względu na zły stan zachowania zabytku noty kancelaryjne zawierające informacje o członkach kancelarii papieskiej biorących udział w kolejnych etapach wygotowania dokumentu ${ }^{17}$ są słabo czytelne. W lewym dolnym rogu karty (sub plica sinistra) widnieją dwie noty: Gratis pro deo Jacobus [...] de Antiquis [...], a poniżej: Gratis pro deo nu[mer]at M. de Novaria (il. 4). Jak wynika z powyższych zapisów, papiescy procuratores nie pobrali opłat przysługujących im z tytułu wykonanych procedur kancelaryjnych. Analogiczną treść (gratis pro deo), lecz bez imienia wykonawcy czynności, zawiera nota dorsalna (in tergo), tj. zapis na stronie grzbietowej dokumentu. Kolejne dwie krótkie noty umieszczone w prawym dolnym rogu dokumentu (sub plica dextra) są nieczytelne.

Jak już wcześniej wspomniałam, rękopis „poznański” jest przykładem dokumentu typu littera exsecutoria, a więc listu zawierającego

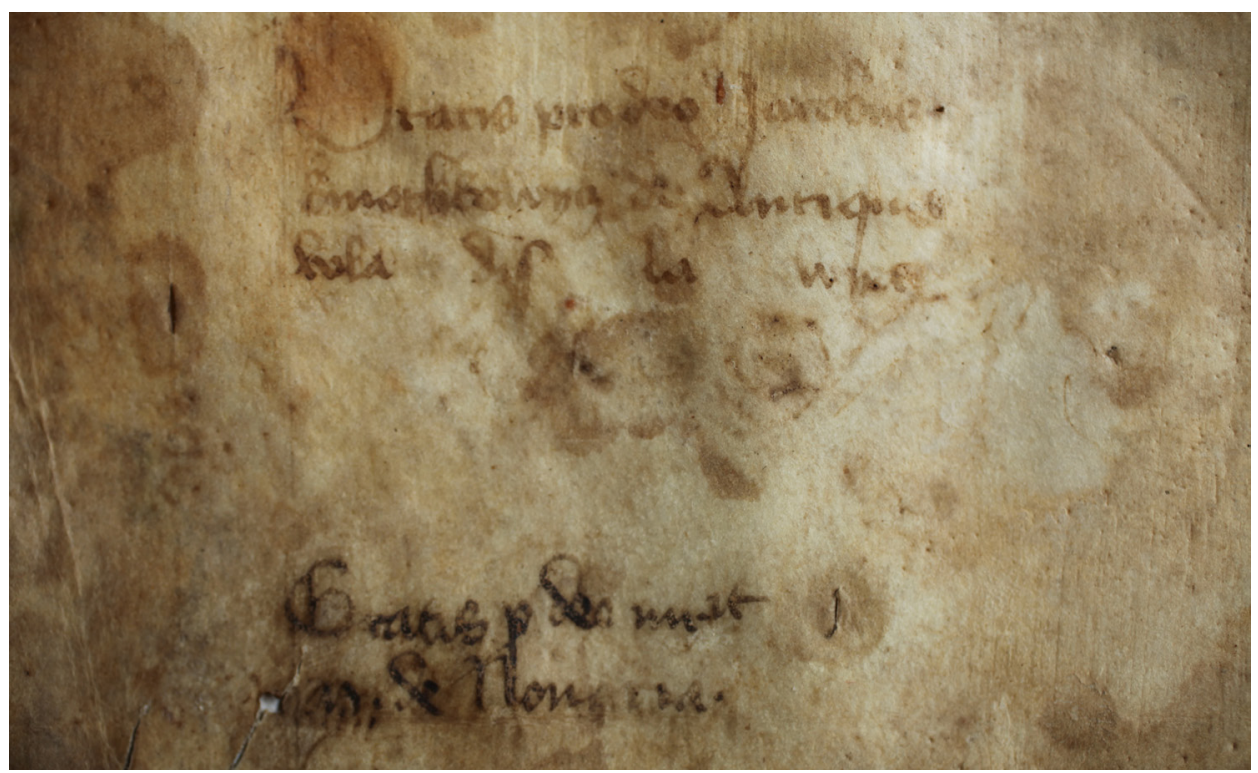

Il. 4. Dokument Innocentego VII z 1404 roku. Noty kancelaryjne w lewym dolnym rogu karty

Źródło: Biblioteka Uniwersytecka w Poznaniu, Rkp.7849. Fot. Renata Kosiniec.

17 O składzie kancelarii papieskiej w XIV-XVI wieku i funkcjach jej członków zob. P. Rabikauskas, Diplomatica pontificia (Praelectionum lineamenta), Roma 1970, s. 87-93. 
papieskie polecenie (mandatum) dotyczące spraw administracyjnych bądź sądowych. Charakterystycznymi formułami i elementami występującymi w średniowiecznych listach papieskich, na podstawie których można stwierdzić, że mamy do czynienia z tego rodzaju dokumentem, są: pozdrowienie salutem et apostolicam benedictionem $\mathrm{w}$ protokole wstępnym dokumentu oraz zwrot per apostolica scripta mandamus w dyspozycji dokumentu. Formuła datalna nie jest zapisana w oddzielnym wierszu, lecz w jednym ciagu: datum (lub abrewiacja dat.), następnie miejsce wystawienia dokumentu, dzień i miesiąc według kalendarza rzymskiego oraz rok pontyfikatu ${ }^{18}$. Littera sygnowane były pieczęcią ołowianą przywieszaną na sznurze konopnym (cum filo canapis) w przypadku mandatów zwykłych, takich jak "poznański”, bądź jedwabnym (cum filo sercio) w przypadku przywilejów ${ }^{19}$.

Omawiane mandatum Innocentego VII składa się z wszystkich podstawowych części dokumentu średniowiecznego, wypracowanych (bądź przejętych z kancelarii cesarskiej) i stosowanych przez cancellaria pontifica $\mathrm{w}$ średniowieczu. Nie zawiera w tym względzie żadnych nietypowych formuł czy wyrażeń odbiegających od schematu litterae exsecutoriae. Najważniejszy przekaz tego dokumentu to informacje dotyczące beneficjum, osoby duchownego, którego dotyczy papieska rezerwacja, lokalizacji beneficjum i data wystawienia mandatum. Krytyczny stan zachowania dokumentu, uszkodzenia pergaminu, liczne plamy i miejsca wytarcia pisma spowodowały, że właśnie te dla nas najcenniejsze treści nie są w pełni czytelne. Innocentius episcopus seruus seruorum Dei przesyła apostolskie błogosławieństwo venerabili fratri archiepiscopo Pragensi i, przychylając się do prośby dilecti filii Johannis [...] de pulcromonte (?) pauperis clerici tue dioecesis, poleca arcybiskupowi przekazać wspomnianemu duchownemu wakujące beneficjum kościelne z posiadłości należących według prawa ad collationem uel presentacionem dilectorum filiorum abbatis et conventus monasterii in Pomuk Cisterciensis ordinis dicte tue diocesis. Pole tekstu, w którym odnotowane jest imię i pochodzenie nominowanego na beneficjum duchowego, jest silnie zaplamione i częściowo wytarte. Z dużym prawdopodobieństwem można jednak stwierdzić, że zapis brzmi: Johannis [...] de pulcromonte. Na tej podstawie można przyjąć, że nominowany przez papieża duchowny to niejaki Jan ze Šumperka (łac. Pulcromonte, niem. Schönberg) koło Ołomuńca.

18 Ibidem, s. 43, 76 i n.

19 Ibidem, s. 43; K. Maleczyński, M. Bielińska, A. Gąsiorowski, Dyplomatyka wieków średnich, Warszawa 1971, s. 53. 
Również odczytanie pełnej formuły datalnej dokumentu nastręcza trudności, ponieważ zapis daty dziennej (według kalendarza rzymskiego) jest znacznie wytarty: Datum Rome apud Sanctumpetrum [...] kal[endis] decembris pontificatus nostri anno primo. Ze względu na brak zapisu daty rocznej od Narodzenia Chrystusa (annus inacarnationis) ${ }^{20}$ i występujący $\mathrm{w}$ intytulacji zapis imienia papieża jedynie $\mathrm{w}$ formie Innocentius (a nie Innocentius VII, jak byłoby w papieskim breve $)^{21}$ data wystawienia dokumentu została ustalona na podstawie kilku pośrednich przesłanek, takich jak: data pontyfikalna (pontificatus nostri anno primo), czas istnienia opactwa w Pomuku, dukt pisma oraz odnotowany w zapisce kancelaryjnej inicjał imienia papieskiego notariusza $M$. de Novaria, występujący w wielu dokumentach Innocentego VII.

Czas wystawienia dokumentu „poznańskiego” - początek XV wieku to okres szczególnie trudny w dziejach zarówno Kościoła powszechnego, czeskiego, jak i pomuckiego opactwa. Trwająca od 1378 roku schizma zachodnia, podział Europy na przeciwstawne obediencje - rzymską i awiniońska, pogłębiony w 1409 roku na soborze w Pizie przez wybór trzeciego papieża („pizańskiego”), spowodowały upadek autorytetu władzy kościelnej, na wszystkich szczeblach, jej wzmożoną krytykę, a co za tym idzie - rozwój idei koncyliaryzmu, wzrost tendencji reformatorskich, odśrodkowych, balansujących niekiedy na granicy ortodoksji. Ten ostatni kierunek ujawnił się szczególnie silnie w Czechach. Głoszone przez Jana Husa radykalne idee reformy Kościoła, w połączeniu ze wzrostem nastrojów antyfeudalnych i antyniemieckich, zaowocowały pierwszym w tej części Europy ruchem religijno-społecznym o charakterze heterodoksyjnym ${ }^{22}$. Odcisnął on piętno w dziejach czeskiego Kościoła, przede wszystkim w życiu wielu wspólnot zakonnych, czego przykładem są losy opactwa cystersów w Pomuku.

W obawie przed atakiem husytów archiwum klasztoru zostało w 1418 roku przeniesione do macierzystego opactwa w Ebrach, gdzie

${ }^{20}$ Zapis Annus a Christo nato $\mathrm{w}$ datacji dokumentów papieskich był powszechnie stosowany dopiero od 1431 roku, tj. od pontyfikatu Eugeniusza IV; P. Rabikauskas, Diplomatica pontificia..., s. 77.

${ }^{21}$ P. Rabikauskas, O znaczeniu słów „,bulla” i „breve”, "Informationes” 1989, t. 4, s. 58 (tłum. poszerzonego artykułu De significatione verborum "bulla", breve”, ,Periodica de Re Morali, Canonica, Liturgica" 1966, t. 55, s. 85-92).

22 S. Bylina, Czeska myśl reformatorska w drugiej połowie XIV wieku i jej echa na Śląsku, „Zeszyty Naukowe KUL” 1978, nr 3-4, s. 63-83. 
schroniła się także większa część pomuckiego konwentu (liczącego wówczas 40 zakonników i braci konwersów). Rok później radykalny kaznodzieja Mikulaš z Husi i jego zwolennicy zajęli Zeleną Horę, tworząc na wzgórzu przyczółek rozwijającego się ruchu ${ }^{23}$. W kwietniu 1420 roku opactwo pomuckie zostało zniszczone przez oddziały husyckie i spalone. Jednak instytucjonalnie nie przestało wówczas jeszcze istnieć. Posiadłości klasztorne zostały zapisane przez króla Zygmunta Luksemburskiego jako zastaw Bogusławowi ze Švamberka. Złożył on jednak zobowiązanie, że zapewni utrzymanie dziewięcioosobowemu konwentowi ${ }^{24}$.

W 1509 roku doszło do próby ustabilizowania sytuacji finansowej opactwa, ale nawet spłacenie zaległych długów klasztoru nie wpłynęło na poprawę jego kondycji materialnej. Ostatecznie w 1558 roku majątek klasztorny przeszedł, wraz z całą zielonogórską posiadłościa, w dziedziczne posiadanie miejscowego możnowładcy Adama ze Šternberka, co stało się ostateczną przyczyną upadku opactwa ${ }^{25}$. Zagłady pomuckiego klasztoru dopełniło zniszczenie jego archiwum. Zdeponowane w opactwie Ebrach, w 1583 roku nakazem cesarza Rudolfa II zostało wydane podskarbiemu dolnoaustriackiej komory Sebaldowi z Plavna i od tej pory ślad po nim zaginął. Nie można wykluczyć, że jego rozproszenie i zniszczenie było celowe, aby ostatecznie usunacc dowody ewentualnych roszczeń majątkowych cystersów ${ }^{26}$. Niezależnie od prawdziwych przesłanek i motywacji, jakie przyświecały władzom rekwirującym archiwum klasztoru spod Zelenej Hory, dla badaczy najistotniejszy jest fakt, że dokumenty cystersów pomuckich zaginęły, a ich dzieje "okrywają ciemności"27.

W tym kontekście dokument „poznański” nabiera szczególnej wartości jako jeden z nielicznych ocalałych (pisanych) śladów bytności białych mnichów na pilzneńskiej ziemi. Jaką drogę przebył list Innocentego VII, zanim z Pragi (Pomuka) trafił do Poznania? Przez jaką introligatornię przeszedł i do jakiego kodeksu został użyty jako okładzina książkowa? Czy była to księga cysterska, czy może nie była związana z tym środowiskiem

${ }^{23}$ F. Šmahel, Husitská revoluce, t. 2: Kořeny české reformace, Praha 1993, s. 314. Szczegółowe dzieje opactwa w Pomuku w okresie wojen husyckich zob. J. Čechura, Mikulaš z Husi a Zelená Hora (Klašter Pomuk na počatku husitství), „Minulostí západočeského krajeę" 1982, t. 18, s. 199-209.

${ }^{24}$ Niewielu zakonników powróciło do Pomuka po 1420 roku. Część pozostała w Ebrach, część rozpierzchła się po terytorium Rzeszy; K. Charvátová, Dějiny cisterckého řádu..., s. 214; J. Čechura, Wirtschaftsmodell der Zisterzienserklöster..., s. 106.

${ }^{25}$ Losy klasztoru w Pomuku po 1420 roku przedstawił szczegółowo A. Berndorf, Klášter pod Zelenou Horou, Plzeň 1929, s. 31-35.

${ }^{26}$ K. Charvátová, Dějiny cisterckého řádu..., s. 214, 240.

${ }^{27}$ K. Charvátová, Early Cistercian economy..., s. 284. 
zakonnym? Te i wiele innych frapujących pytań dotyczących losów odnalezionego dokumentu pozostanie już jednak zapewne bez odpowiedzi.

W edycji tekstu dokumentu zachowuję oryginalną pisownię, wprowadzam jedynie duże litery w nazwach własnych oraz znaki interpunkcyjne. Fragmenty nieczytelne zaznaczam nawiasem kwadratowym.

Innocentius [Pp. VII] archiepiscopo Pragensi mandat, ut Johanni de Pulcromonte (?), pauperi clerico Pragensis dioecesis, de beneficio ecclesiastico ad collacionem abbatis et conventus monasterii in Pomuk Cisterciensis ordinis dicte diocesis pertinente providere procuret. Romae, [1404] [...] kalendis decembris.

Innocentius episcopus, seruus seruorum Dei, venerabili fratri archiepiscopo Pragensi salutem et apostolicam benedictionem. Dilecti filii Johannis [...] de Pulcromonte (?) pauperis clerici tue diocesis apud sedem apostolicam constituti supplicationibus inclinati fraternitati tue per apostolica scripta mandamus, quatinus de uita et conuersacione ipsius clerici, qui, ut asserit, aliquod beneficium ecclesiasticum non obtinet et quem per certos examinatores super hoc deputatione a nobis de litteratura examinari fecimus diligenter, quique in illa repertus est ydoneus ad ecclesiasticum beneficium obtinendum, solerter inquirens, si eum uite laudabilis et honeste conuersationis esse reppereris et aliud beneficium ecclesiasticum non obtineat aliudque canonicum non obsistat, ei de aliquo beneficio ecclesiastico, cum cura uel sine cura, consueto ab olim clericis secularibus assignari, dummodo in ecclesia cathedrali non existat, cuius fructus, redditus et prouentus, si cum cura viginti si uero sine cura fuerit quindecim marcharum argenti secundum taxacionem decime, si taxatum fuerit, uel si taxatum non fuerit secundum quod de ipso pro decima communiter persolui consueuit, ualorem annuum non excedant, ad collationem uel presentacionem dilectorum filiorum abbatis et conventus monasterii in Pomuk Cisterciensis ordinis dicte tue diocesis communiter vel divisim pertinente, si [quod?] in ciuitate Pragensi vel dicta diocesi uacat ad presens uel cum uacauerit, quod idem clericus infra vnius mensis spacium, postquam sibi de ipsius beneficii uacatione constiterit, duxerit acceptandum, auctoritate nostra prouidere procures, inducens per alium seu alios eundem clericam in corporalem possessionem huiusmodi beneficii et deffendens inductum ac faciens ipsum ad illud, eciam si canonicatus (?) et prebenda fuerit, ut est moris, admitti sibique de ipsius beneficii 
fructibus, redditibus, prouentibus, iuribus et obuentionibus uniuersis integre responderi, contradictores [...] usuram ecclesiasticam apellatione postposita compescendo. Non obstantibus, si aliqui super prouisionibus sibi faciendis dehuiusmodi uel aliis beneficiis ecclesiasticis in illis partibus generales uel speciales dicte sedis uel legatorum eius sub quacumque uerborum forma litteras (?) impetrarint, eciam si per eas ad inhibitionem, reseruationem et decretum uel alias quomodolibet sit processum quibus omnibus preterquam auctoritate nostra huiusmodi beneficia expectantibus in eiusdem beneficii assecutione dictum clericum uolumus anteferri, sed nullum per hoc eis quo ad assecutionem beneficiorum aliorum preiudicium generari, seu si [...] abbati et conventum vel quibusuis aliis communiter uel diuisim ab eadem sit sede indultum, quod ad receptionem uel prouisionem alicuius minime teneantur et ad id compelli aut quod interdici, suspendi uel excommunicari non possint, quodque de beneficiis ecclesiasticis ad eorum collationem uel presentationem coniunctim uel separatim spectantibus nulli valeat prouideri per litteras apostolicas non facientes plenam et expressam ac de uerbo ad uerbum de indulto huiusmodi mentionem et qualibet alia dicte sedis indulgencia generali uel speciali, cuiuscumque tenoris existat, per quam presentibus non expressam uel totaliter non insertam effectus earum impediri ualeat quomodolibet uel differri et de qua cuiusque toto tenore habenda sit in nostris litteris mencio specialis.

Volumus autem, quod si tu presentes litteras non potueris seu nolueris exequi, dilecti filii prepositus et decanus ecclesie pragensis littears ipsas ac omnia et singula in eis contenta secundum ipsarum litterarum tenorem exequi possint et debant super quo eis tenore presencium mandatum damus et eciam potestatem.

Et insuper prefatis abbati et conventui ne de huiusmodi beneficio interim eciam ante insinuationem presencium et processuum per eas habitorum ei factam, nisi postquam eis constiterit, quod idem clericus beneficium huiusmodi acceptare noluerit, disponere quoquomodo presumant districcius inhibemus, decernentes irritum et inane, si secus super premissis a quoquam quauis auctoritate scienter uel ignoranter contigerit attemptari. Datum Rome apud Sanctumpetrum [...] kal[endis] decembris pontificatus nostri anno primo. 


\section{Bibliografia}

Źródła

Acta summorum pontificum res gestas Bohemicas aevi praehussitici et hussitici illustrantia, cz. 1, wyd. Jaroslav Eršil, Praha 1980.

Mateusz z Krakowa, O praktykach Kurii Rzymskiej, wyd., przeł. W. Seńko, Kęty 2007.

Literatura przedmiotu

Bylina S., Czeska myśl reformatorska w drugiej połowie XIV wieku i jej echa na Ślasku, "Zeszyty Naukowe KUL" 1978, nr 3-4, s. 63-83.

Charvátová K., Manorial farms of Cistercian abbeys of mediaeval Bohemia, w: Historia i kultura cystersów w dawnej Polsce i ich europejskie związki, red. J. Strzelczyk, Poznań 1987.

Charvátová K., Propter laudabilia abbatum merita. The Kings of Bohemia and the Cistercian Order, w: In Tal und Einsamkeit. 725 Jahre Kloster Fürstenfeld. Die Zisterzienser im alten Bayern, t. 3, red. K. Wollenberg, Fürstenfeldbruck 1990.

Charvátová K., Der Bau der Zisterzienserklöster in Böhmen, w: Cystersi w kulturze średniowiecznej Europy, red. J. Strzelczyk, Poznań 1992.

Charvátová K., Dějiny cisterckého řádu w Čechách 1142-1420. 1. svazek: Fundace 12. stoleti, Praha 1998.

Charvátová K., Libal D., Pojsl M., ̌̌ád cisterciáků v českých zemich ve středověku, Praha 1994.

Charvátová K., Early Cistercian economy in Bohemia (about 1150-1300): the mysterious affair of the granges, "Quaestiones medii aevi novae” 2004, t. 9, s. 283-296.

Chłopocka H., Schich W., Die Ausbreitung des Zisterzienserordens östlich von Elbe und Saale, w: Die Zisterzienser. Ordensleben zwischen Ideal und Wirklichkeit, red. K. Elm, P. Joerißen, H.J. Roth, Bonn 1980.

Čechura J., Mikulaš z Husi a Zelená Hora (Klašter Pomuk na počatku husitstoí), „Minulostí západočeského kraje" 1982, t. 18, s. 199-209.

Čechura J., Wirtschaftsmodell der Zisterzienserklöster in Böhmen, w: Historia i kultura cystersów w dawnej Polsce i ich europejskie związki, red. J. Strzelczyk, Poznań 1987.

Eberl I., Cystersi. Historia zakonu europejskiego, Kraków 2011.

Elm K., Feige P., Der Verfall des zisterziensischen Ordenslebens im späten Mittelalter, w: Die Zisterzienser. Ordensleben zwischen Ideal und Wirklichkeit. Ergänzungsband, red. K. Elm, P. Joerißen, Köln 1982.

Machilek F., Stiftergedächtnis und Klosterbau in der Chronik des Heinrich von Saar, w: In Tal und Einsamkeit. 725 Jahre Kloster Fürstenfeld. Die Zisterzienser im alten Bayern, t. 3, red. K. Wollenberg, Fürstenfeldbruck 1990.

Rabikauskas P., Diplomatica pontificia (Praelectionum lineamenta), Roma 1970.

Ribbe W., Die Wirtschaftstätigkeit der Zisterzienser im Mittelalter: Agrarwirtschaft, w: Die Zisterzienser. Ordensleben zwischen Ideal und Wirklichkeit. Ergänzungsband, red. K. Elm, P. Joerißen, Köln 1982. 
Rösener W., Grangienwirtschaft und Grundbesitzorganisation südwestdeutscher Zisterzienserklöster vom 12. Bis 14. Jahrhundert, w: Die Zisterzienser. Ordensleben zwischen Ideal und Wirklichkeit. Ergänzungsband, red. K. Elm, P. Joerißen, Köln 1982.

Schimmelpfenning R., Zisterzienser, Papsttum und Episkopat im Mittelalter, w: Die Zisterzienser. Ordensleben zwischen Ideal und Wirklichkeit. Ergänzungsband, red. K. Elm, P. Joerißen, Köln 1982.

Szulc A., Bohemica w zbiorach rękopisów Biblioteki Uniwersyteckiej w Poznaniu, w: Na styku kultury polskiej i czeskiej: dziedzictwo, kontynuacje, inspiracje, red. M. Balowski, Poznań 2011.

Šmahel F., Husitská revoluce, t. 2: Kořeny české reformace, Praha 1993.

Vlček P., Sommer P., Foltýn D., Encyklopedie českých klásterů, Praha 1998.

Wollenberg K., Die Zisterzienser in Altbayern, Franken und Schwaben - ein Überblick, w: In Tal und Einsamkeit. 725 Jahre Kloster Fürstenfeld. Die Zisterzienser im alten Bayern, t. 3, red. K. Wollenberg, Fürstenfeldbruck 1990.

\title{
ALICJA SZULC \\ Hidden in the binding. On a finding of a medieval document of Pope Innocent VII from 1404 and the Cistercian abbey in Nepomuk
}

\begin{abstract}
Aвstract. A rare document from 1404 issued by Pope Innocent VII was found in the manuscript collection of Poznań University Library in 2008. The document, written on parchment, is addressed to Archbishop of Prague and refers to some ecclesiastical privileges for the Cistercian abbey at Nepomuk in Bohemia. Strictly speaking this is the oldest document that is currently held in the collections of the library. The state of its preservation shows that the document has been reused by an unknown bindery as a wrapping for the wooden binding of a codex, possibly of Cistercian provenance. The manuscript of the type littera exsecutoria (i.e. one that includes a papal instruction - mandatum) has a particular source value as one of the few preserved documents from the archives of the monastery at Nepomuk that was almost entirely destroyed and then dispersed at the time of the Hussite wars in Bohemia. The present article is supplemented with a Latin edition of the document.
\end{abstract}

Key words: Papal documents, Cistercians in the Middle Ages, Innocenty VII, Pomuk, Nepomuk, 15th c. Bohemia. 
